\title{
PRODUCTIVITY MANAGEMENT IN THE CONTEMPORARY ENTERPRISE - ANALYSIS, EVALUATION AND IMPROVEMENT
}

\begin{abstract}
The aim of the article is to analyse the essence of productivity management and its model approach. An index analysis and assessment of productivity in Polish companies are presented. Productivity improvement is a continuous process based on improvement. The research utilised the methods of statistical analysis, content analysis, and descriptive analysis of secondary data. The results of the research involved the development of a comprehensive methodology for improving productivity based on modern concepts, methods, and techniques of production management. To analyse and design the methodology for improving productivity in a production company, and to ensure its proper and effective functioning, it is necessary to implement in stages several organisational, technical and social tasks. Companies that use modern productivity improvement programs are successful because they can quickly and dynamically adapt to changing environmental conditions. The summary emphasises the importance of developing a new methodology to improve productivity through production management practices.
\end{abstract}

Keywords: management, productivity, productivity management, modern production management concepts.

\section{INTRODUCTION}

Productivity is an extremely complex and interdisciplinary problem. It refers to macroeconomic systems, such as the global and national economies, and to microeconomic systems, which include individual companies and jobs.

Productivity growth is seen in the modern world as a source of economic growth, social progress and improved living standard. Actions to improve productivity lead to a better use of the existing production resources. Competition in the domestic and foreign markets forces producers to look for new ways to increase productivity and seek better methods to improve productivity.

\section{THE ESSENCE OF PRODUCTIVITY MANAGEMENT AND ITS MODEL PERSPECTIVE}

The activity of production systems - which, depending on the degree of aggregation, may incorporate the whole enterprises, processes, or individual workstations - can be

\footnotetext{
${ }^{1}$ Renata Piętowska-Laska, PhD, Eng., Department of Management Systems and Logistics, Rzeszów University of Technology, Rzeszów, al. Powstańców Warszawy 12, 35-959 Rzeszów; e-mail: rlaska@prz.edu.pl. ORCID: 0000-0001-5665-0377.
} 
determined by assessing their productivity. The productivity category belongs to the group of problems used to describe management processes. Productivity is a result of an economic activity assessed on the basis of the ratio of the achieved results to the necessary outlays incurred to obtain those results (Piętowska-Laska, 2015).

Contemporary determination of productivity is manifested in the dual approach to the term productivity, namely:

- economic and social, i.e. focusing the way of thinking on a constant search for ways to improve the current state of the system,

- technical, which is a measure of the efficiency of the system.

The socioeconomic approach is intended to clarify what the concept of productivity means in the broad context of the production system as well as its immediate and distant environment. It is useful in the situation of determining the "standard" that the organisation tries to achieve, which indicates the desired directions of development of the production system. Therefore, it can be used to specify and explain the organisation's strategic objectives. In technical terms, however, productivity is defined as the relation between the output (goods produced, services provided) and the input (resources used) in the production transformation process.

The productivity level is an important factor in improving the competitiveness of enterprises. The productivity management process consists of closely intertwined stages (Fig. 1).

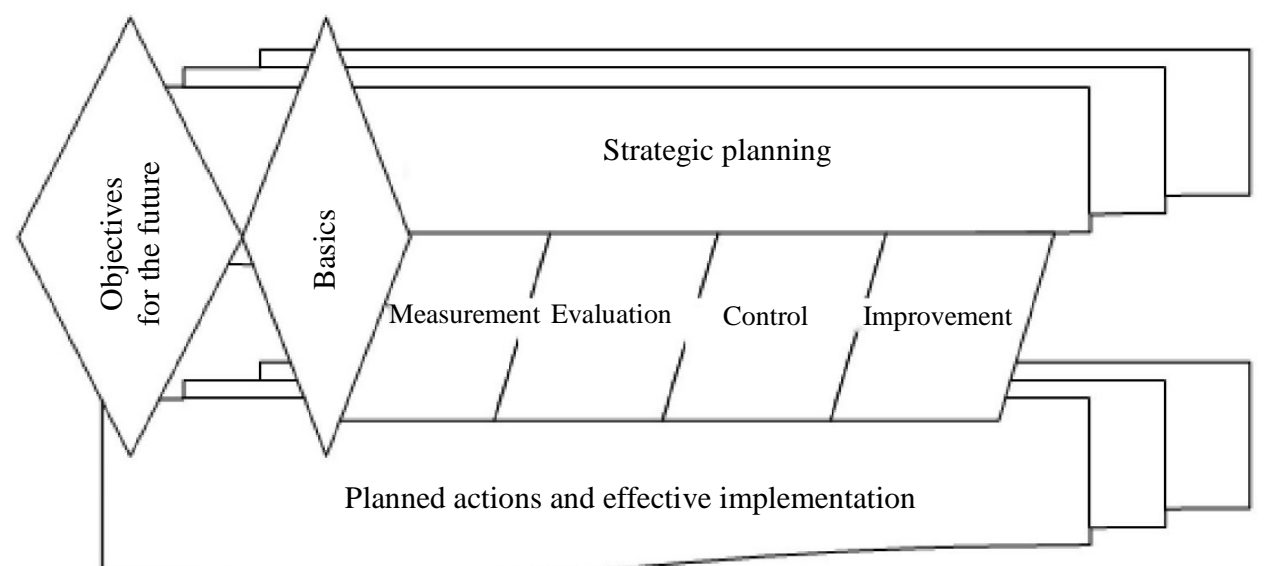

Figure 1. Productivity management process

Source: Author's own elaboration based on: (Sink, 1985; Kosieradzka, Lis, 2000).

Methods and techniques of improving production processes in order to improve their productivity are taken up by: R. Harris, Ch. Harris, E. Wilson (Harris, Harris, Wilson, 2005), D. Jones and J. Womack (Jones, Womack, 2007). Productivity improvement through the use of production engineering tools was considered by H.A. Salaam, S.B. How, M.F. Faisae (Salaam, How, Faisae, 2012). Achieving productivity growth using Lean Manufacturing to reduce cycle time for manufacturing processes using Value Stream Mapping (VSM) was presented by B. Vijaya Ramnath, Vishal Chandrasekhar, C. 
Elanchezhian, L. Vinoth Selva Bruce, K. Venkataraman (Vijaya Ramnath, Vishal Chandrasekhar, Elanchezhian, Vinoth Selva Bruce, Venkataraman, 2014). Implementation of Lean tools together with work research methods was the subject of research by P.P. Kulkarni, S.S. Kshire, K.V. Chandratre (Kulkarni, Kshire, Chandratre, 2014). Whereas, I. Dincută-Tănasea, C. Bordea, E. Câmpeana, D. Pop proposed a way of determining productivity levels for qualitative and quantitative factors (Dincută-Tănasea, Bordea, Câmpeana, Pop, 2014).

In order to improve productivity in manufacturing companies, the use of new technologies or the adoption of mass production may not always be possible. Therefore, the most practical approach is the analysis of work processes, i.e. review and redesign of activities and the application of modern production management concepts, methods and techniques. In fact, only companies using modern productivity improvement programs are successful at present, as they can rapidly and dynamically adjust to the changing conditions of the environment.

\section{ANALYSIS, ASSESSMENT AND PRODUCTIVITY IMPROVEMENT IN POLISH COMPANIES}

In order to be able to control its market position and to adapt to changing environmental conditions through continuous improvement of the existing state, an enterprise should have a productivity measurement system in place. The selection of indicators for the productivity measurement system depends on many factors that make up the specific situation of the company. The most important thing is to ensure that the productivity measurement system is coupled with the company's economic and financial system and the system of planning and recording production as well as with the system of recording production costs. Productivity is therefore a very "capacious" measure of how effectively and efficiently an organisation performs its tasks, how efficient and effective it is in achieving its objectives and how comparable it is to its competitors.

In order to manage a company efficiently, it is necessary to constantly analyse various sets of indicators used in the evaluation of its own activities. According to the observations made in many Polish enterprises, the vast majority of them have implemented financial controlling, including profitability, liquidity, debt and capital activity ratios, while productivity ratios are observed and analysed rather sporadically and accidentally. It is worth noting that this does not make use of the great opportunities and benefits resulting from their analysis. Productivity assessment is an essential and valuable complement to standard financial analysis of the business for decision making at all levels of management.

The observation, analysis and evaluation of productivity in a company is therefore a tool for effective management, leading to (Kosieradzka, 2012):

- assessment of the company performance compared with other businesses, in particular within the same sector,

- identification of the areas of activity that are characterized by low productivity and need to be improved,

- formulation of the company productivity improvement programs and strategic plans,

- observation of trends in changes in the productivity indicators, thanks to which it is possible to introduce early warning mechanisms for possible threats and opportunities for the company, 
- providing feedback on the effects of previously introduced productivity improvement programs,

- links between the HR and payroll policies of the enterprise and the productivity of its organisational units.

In order for a company to be able to effectively control its productivity and to consciously influence the way it increases, it must have an effective and rapid tool at its disposal to assess productivity. These requirements are met by the indicator method based on the analysis of a properly selected set of productivity indicators. The productivity measures can therefore be classified according to:

- definition of productivity: 1 . direct - indicators expressed as a quotient of production effects to outlays sustained (technical approach to productivity); 2 . indirect - beyond the technical approach, e.g. measures related to the quality of work and related to the level of shortages, costs of shortages in production costs, etc.,

- complexity: 1. comprehensive - general for the whole company; 2. partial - productivity indicators of capital, materials, energy and labour,

- parameter expression method: 1. physical - are based on the expression of products and resources only in physical units (e.g. pieces, kilograms, minutes, kilowatt-hours, etc.); 2. economic - use, in addition to "physical" parameters, also amounts expressed in value (product prices, costs of resources, exchange rates, etc.),

- hierarchy: 1. measures for the company - evaluation of the effectiveness of the organisation as a whole; 2. measures for processes - evaluation of the effectiveness of processes implemented in the organisation; 3. measures of jobs - evaluation of job performance (Rostek, Knosala, 2014).

The presented research results concern labour productivity, which is now recognized in the literature as one of the most important indicators of the real prosperity of every enterprise, which processes employees' efforts as the input into specific outputs.

The increase in labour productivity taking place in Poland applies both to the whole economy and manufacturing enterprises. In the period 2008-2017, labour productivity growth measured by gross value added per 1 employee reached a growth of $163.5 \%$ in Poland, and was even higher for the manufacturing business $-165.4 \%$. Productivity growth was recorded in all parts across the manufacturing sector, although in some of them oneyear slowdowns in labour productivity growth can be observed (Table 1).

The analysis of speed of the labour productivity growth measured by sales per $1 \mathrm{em}-$ ployee in selected sectors reveals the possibility of strong changes in labour productivity levels in some sectors. This is influenced by the internal and international conditions of the sectors (Fig. 1).

The achieved speed of labour productivity growth of particular sectors and divisions of the national economy allows to determine and make strategic decisions concerning further economic development of the country. It is also an effective indicator for assessing the correctness of the economic decisions made so far. This applies in particular to those sectors that can and do compete on international markets and the decisions e.g. about investments made, payroll policy, pricing, tax, customs policies etc. 
Productivity management in the contemporary enterprise ...

Table 1. Labour productivity in industry measured by gross value added per 1 employee according to sections and divisions in the period 2008-2017

\begin{tabular}{|c|c|c|c|c|c|c|c|c|c|c|}
\hline \multirow{2}{*}{ SECTIONS AND DIVISIONS } & 2008 & 2009 & 2010 & 2011 & 2012 & 2013 & 2014 & 2015 & 2016 & 2017 \\
\hline & \multicolumn{10}{|c|}{ in thousands } \\
\hline TO T A L & 97,4 & 111,8 & 116,4 & 128,0 & 138,2 & 139,5 & 144,5 & 154,2 & 156,9 & 159,3 \\
\hline Industrial processing & 86,2 & 99,8 & 100,8 & 110,8 & 120,0 & 120,5 & 128,3 & 138,2 & 141,3 & 142,6 \\
\hline Production of food products & 70,3 & 86,0 & 88,2 & 86,9 & 97,5 & 100,7 & 101,5 & 111,4 & 115,8 & 126,4 \\
\hline Production of beverages & 193,3 & 297,5 & 213,6 & 188,2 & 200,4 & 220,5 & 251,8 & 251,9 & 270,5 & 251,0 \\
\hline Production of tobacco products & 296,7 & 388,1 & 538,1 & 661,1 & 761,9 & 765,7 & 883,7 & 1033,4 & 1006,6 & 904,6 \\
\hline Production of textile products & 50,5 & 57,4 & 64,7 & 67,0 & 78,8 & 78,3 & 87,3 & 89,6 & 92,1 & 91,4 \\
\hline Production of clothing & 31,4 & 37,9 & 39,1 & 43,1 & 47,3 & 48,1 & 53,0 & 57,4 & 59,2 & 69,1 \\
\hline $\begin{array}{l}\text { Production of leather and leather } \\
\text { products }\end{array}$ & 40,6 & 43,5 & 49,2 & 52,0 & 55,4 & 63,2 & 70,0 & 72,7 & 73,0 & 78,3 \\
\hline $\begin{array}{l}\text { Production of wood, cork, straw and } \\
\text { wicker products }\end{array}$ & 65,6 & 78,8 & 78,1 & 85,4 & 93,8 & 95,7 & 104,7 & 106,3 & 109,9 & 117,9 \\
\hline $\begin{array}{l}\text { Production of paper and paper } \\
\text { products }\end{array}$ & 103,5 & 124,2 & 129,2 & 136,9 & 159,7 & 161,9 & 180,0 & 190,0 & 191,8 & 196,2 \\
\hline $\begin{array}{l}\text { Printing and reproduction of recorded } \\
\text { media }\end{array}$ & 121,8 & 134,3 & 119,7 & 128,3 & 132,8 & 127,5 & 139,9 & 144,5 & 151,6 & 149,0 \\
\hline $\begin{array}{l}\text { Production of coke and refined petro- } \\
\text { leum products }\end{array}$ & 569,4 & 507,2 & 683,7 & 860,1 & 897,5 & 788,9 & 454,4 & 698,9 & 795,7 & 820,4 \\
\hline $\begin{array}{l}\text { Production of chemicals and chemical } \\
\text { products }\end{array}$ & 127,2 & 130,4 & 152,5 & 178,6 & 186,0 & 177,7 & 190,7 & 225,1 & 236,8 & 222,2 \\
\hline Production of pharmaceuticals & 185,4 & 204,1 & 206,7 & 195,6 & 226,5 & 238,9 & 274,2 & 252,8 & 255,3 & 247,0 \\
\hline $\begin{array}{l}\text { Production of rubber and plastic } \\
\text { products }\end{array}$ & 79,4 & 96,2 & 102,5 & 105,1 & 114,4 & 122,7 & 127,8 & 131,4 & 135,6 & 133,9 \\
\hline $\begin{array}{l}\text { Manufacture of products from other } \\
\text { mineral non-metallic raw materials }\end{array}$ & 115,8 & 116,2 & 117,1 & 124,5 & 121,3 & 120,2 & 136,8 & 146,7 & 153,6 & 156,0 \\
\hline Production of metals & 88,6 & 103,3 & 81,2 & 121,3 & 123,9 & 118,6 & 148,6 & 153,2 & 159,2 & 149,5 \\
\hline Production of goods from metals & 80,8 & 84,4 & 93,2 & 106,4 & 110,8 & 107,5 & 118,7 & 131,8 & 131,6 & 132,8 \\
\hline $\begin{array}{l}\begin{array}{l}\text { Manufacture of computer, electronic } \\
\text { and optical products }\end{array} \\
\end{array}$ & 91,5 & 153,2 & 110,6 & 110,2 & 116,9 & 115,3 & 129,7 & 123,9 & 131,6 & 123,6 \\
\hline Production of electrical equipment & 94,6 & 102,0 & 107,1 & 110,0 & 121,3 & 119,2 & 129,5 & 144,0 & 137,1 & 122,0 \\
\hline $\begin{array}{l}\text { Production of machinery and equip- } \\
\text { ment }\end{array}$ & 82,7 & 102,0 & 99,9 & 110,0 & 112,0 & 107,9 & 118,7 & 120,3 & 121,3 & 129,1 \\
\hline $\begin{array}{l}\text { Production of motor vehicles, trailers } \\
\text { and semi-trailers }\end{array}$ & 94,1 & 114,4 & 111,9 & 134,6 & 139,2 & 141,5 & 145,2 & 156,5 & 159,5 & 157,2 \\
\hline $\begin{array}{l}\text { Production of other transport equip- } \\
\text { ment }\end{array}$ & 59,9 & 85,2 & 89,4 & 123,2 & 140,9 & 144,8 & 172,0 & 161,0 & 158,5 & 167,6 \\
\hline Production of furniture & 52,5 & 71,6 & 64,1 & 67,4 & 71,6 & 74,9 & 85,7 & 82,9 & 90,6 & 87,2 \\
\hline Other manufacturing of products & 77,4 & 92,5 & 90,6 & 95,0 & 113,6 & 107,0 & 122,4 & 129,0 & 132,8 & 127,0 \\
\hline $\begin{array}{l}\text { Repair, maintenance and installation of } \\
\text { machinery and devices }\end{array}$ & 119,3 & 88,6 & 96,7 & 117,9 & 151,9 & 151,0 & 160,9 & 192,6 & 174,3 & 190,7 \\
\hline
\end{tabular}

Source: Author's own calculations based on: (Industrial Statistical Yearbook 2016 [2017]; Industrial Statistical Yearbook 2017 [2018]). 


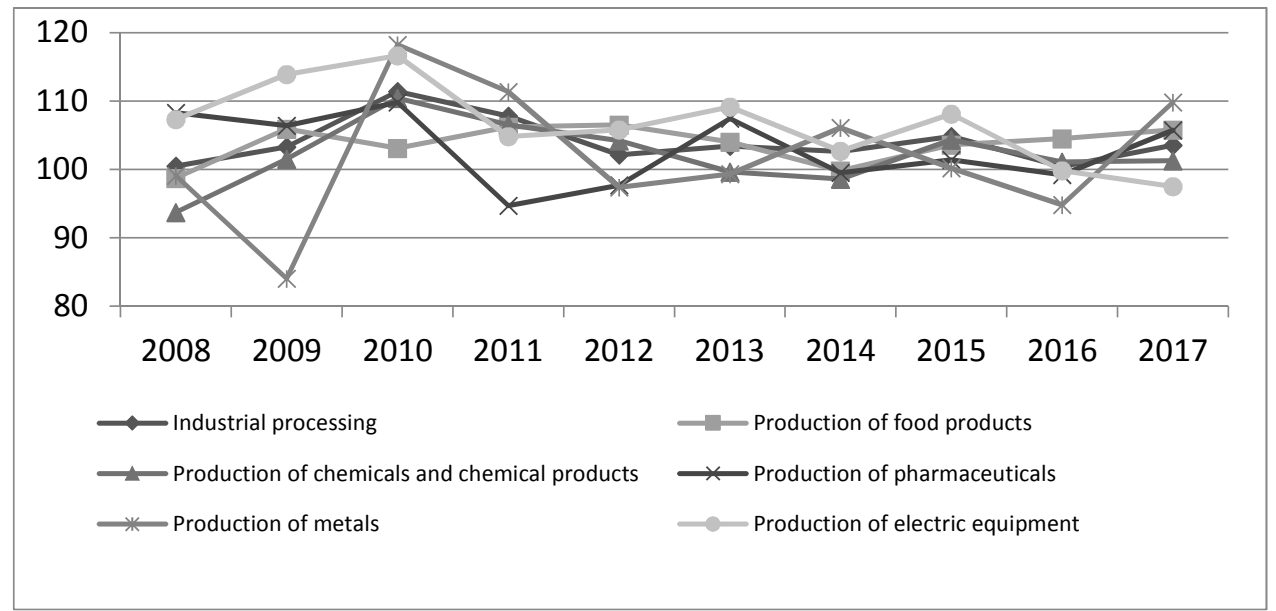

Fig. 1Labor productivity growth rate measured by the volume of sales per 1 employee in selected industrial processing sectors (previous year $=100 \%$ ).

Source: Author's own calculations based on: (Industrial Statistical Yearbook 2016 [2017]; Industrial Statistical Yearbook 2017 [2018]).

Productivity improvement in Polish enterprises can now be achieved through the development and implementation of productivity improvement programs, which include, in addition to typical activities related to the planning, organisation, management and control of a complex project, also specific aspects, such as the practical application of the $5 \mathrm{~S}$ principles, the ubiquitous Kaizen continuous improvement philosophy, training and development of employees. Actions to improve productivity lead companies to adopt a "productivity culture", meaning a specific set of norms, practices and organisational climate fostering the effective implementation of productivity improvement programs.

A productivity improvement program is a complex technical, organisational and social undertaking carried out with the aim of improving the efficiency of the whole enterprise or its smaller areas. Productivity growth can be achieved by non-investment means (improvement of organisation, improvement in the use of available means of production, labour and labour force) or as a result of projects that require investment outlays. Productivity improvement programs can be local (nest, workplace group or single workplace) or cover the whole company or even suppliers or entire distribution channels (Kosieradzka, Lis, 2000).

\section{COMPLEX PRODUCTIVITY IMPROVEMENT METHODOLOGY}

Productivity improvement consists in changes of a different nature being made at all levels of the enterprise in terms of primary production, secondary production, administrative operations and management.

In order to achieve this goal, each company introduces development programs based primarily on the implementation of modern management concepts, the functioning of which should result in increased productivity (Table 2). 
Table 2. Characteristics of management concepts/methods used in comprehensive productivity improvement methodology

\begin{tabular}{|c|c|c|}
\hline Concept/method & Approach characteristics & Expected benefits \\
\hline Kaizen & $\begin{array}{l}\text { Continuous improvement of pro- } \\
\text { cesses through small improvements } \\
\text { made continuously by all employees }\end{array}$ & $\begin{array}{l}\text { - } \text { shortened production cycles, } \\
\text { - } \text { reduced assembly time, } \\
\text { - } \text { increased productivity, } \\
\text { - } \text { waste reduction, } \\
\text { - } \text { reduction of capital expenditure, } \\
\text { - } \text { reduction of complaints, }\end{array}$ \\
\hline \begin{tabular}{|l|} 
Total Quality Manage- \\
ment \\
(TQM)
\end{tabular} & $\begin{array}{l}\text { Comprehensive business manage- } \\
\text { ment through quality improvement }\end{array}$ & 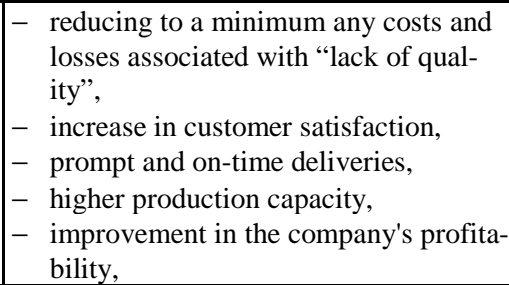 \\
\hline $\begin{array}{l}\text { Total Productivity } \\
\text { Maintenance } \\
\text { (TPM) }\end{array}$ & $\begin{array}{l}\text { Fast changeover of technical re- } \\
\text { sources (production line machines) }\end{array}$ & $\begin{array}{ll}- & \text { labour productivity growth, } \\
\text { - } & \text { reduction in the number of failures, } \\
\text { - } & \text { reduction of internal waste, } \\
\text { - } & \text { reduced number of complaints, } \\
\text { - } & \text { reduced production costs, } \\
\text { - } & \text { reduced stock in progress, } \\
\end{array}$ \\
\hline $\begin{array}{l}\text { Theory of Constraints } \\
\text { (TOC) }\end{array}$ & $\begin{array}{l}\text { Improving performance through } \\
\text { identification and focus on bottle- } \\
\text { necks }\end{array}$ & 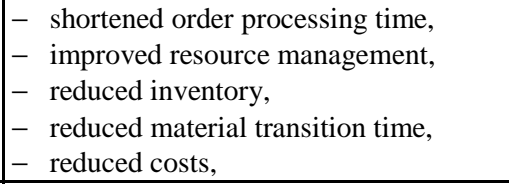 \\
\hline $\begin{array}{l}\text { Agile Manufacturing } \\
\text { (AM) }\end{array}$ & $\begin{array}{l}\text { Immediate reaction to opportunities } \\
\text { and threats appearing in the environ- } \\
\text { ment, } \\
\text { creates and integrates processes, } \\
\text { technologies and employees } \\
\text { equipped with knowledge (produc- } \\
\text { tion knowledge management - Pro- } \\
\text { duction Knowledge Management - } \\
P K M \text { ) in order to allow for a quick } \\
\text { response to the customer's needs (in- } \\
\text { dividualized mass production - } \\
\text { Mass Customisation-MC) }\end{array}$ & $\begin{array}{l}- \text { benefits for all participants (manufac- } \\
\text { turers, suppliers, customers), } \\
\text { - } \text { integration (of resources, methods, } \\
\text { technologies, organisational units and } \\
\text { organisations), } \\
\text { - development of key competences, } \\
\text { - } \\
\text { efficient use of resources, }\end{array}$ \\
\hline $\begin{array}{l}\text { Lean Manufacturing } \\
\text { (LM) }\end{array}$ & $\begin{array}{l}\text { Reduction of costs and maximisa- } \\
\text { tion of profits by eliminating all } \\
\text { losses in the manufacturing process }\end{array}$ & $\begin{array}{ll}- & \text { reduction of shortages, } \\
\text { - } & \text { reduction of changeover times, } \\
- & \text { productivity growth, } \\
\text { - } & \text { reduction of inventory and work in } \\
& \text { progress, }\end{array}$ \\
\hline $\begin{array}{l}\text { Lean Logistics } \\
\text { (LL) }\end{array}$ & $\begin{array}{l}\text { Optimisation of in-house logistics } \\
\text { and warehouse management, slim, } \\
\text { complex material flow }\end{array}$ & $\begin{array}{l}\text { - } \text { reduced product design cost, } \\
- \text { shortened production cycle, } \\
\text { - increased productivity, } \\
\text { - improved production quality, } \\
\text { - } \text { reduced stock of work in progress, } \\
\text { - } \text { reduced personnel costs, }\end{array}$ \\
\hline
\end{tabular}


Table 2 (cd.). Characteristics of management concepts/methods used in comprehensive productivity improvement methodology

\begin{tabular}{|l|l|l|}
\hline \multicolumn{1}{|c|}{ Concept/method } & \multicolumn{1}{|c|}{ Approach characteristics } & \multicolumn{1}{c|}{ Expected benefits } \\
\hline Method Rapid Re ${ }^{T M}$ & $\begin{array}{l}\text { Redesigning the operational process } \\
\text { in a short period of time }\end{array}$ & $\begin{array}{l}\text { shortened production cycles and re- } \\
\text { duced costs, } \\
\text { improved quality of products and cus- } \\
\text { tomer satisfaction, } \\
\text { increased profitability and market } \\
\text { share, }\end{array}$ \\
\hline $\begin{array}{l}\text { Method General Elec- } \\
\text { tric (GE) }\end{array}$ & $\begin{array}{l}\text { Revolutionary implementation of } \\
\text { changes in the company on a contin- } \\
\text { uous basis }\end{array}$ & $\begin{array}{l}\text { increased revenue, } \\
\text { increased net income, } \\
\text { significant increase in productivity, }\end{array}$ \\
\hline $\begin{array}{l}\text { Dynamic Process } \\
\begin{array}{l}\text { Management } \\
\text { (DPM) }\end{array}\end{array}$ & $\begin{array}{l}\text { Rapid response to changing critical } \\
\text { operating conditions }\end{array}$ & $\begin{array}{l}\text { focusing the company on customer } \\
\text { satisfaction, } \\
\text { recognition and ordering of planes that } \\
\text { require improvement. }\end{array}$ \\
\hline
\end{tabular}

Source: Author's own elaboration based on: (Danielak, 2008).

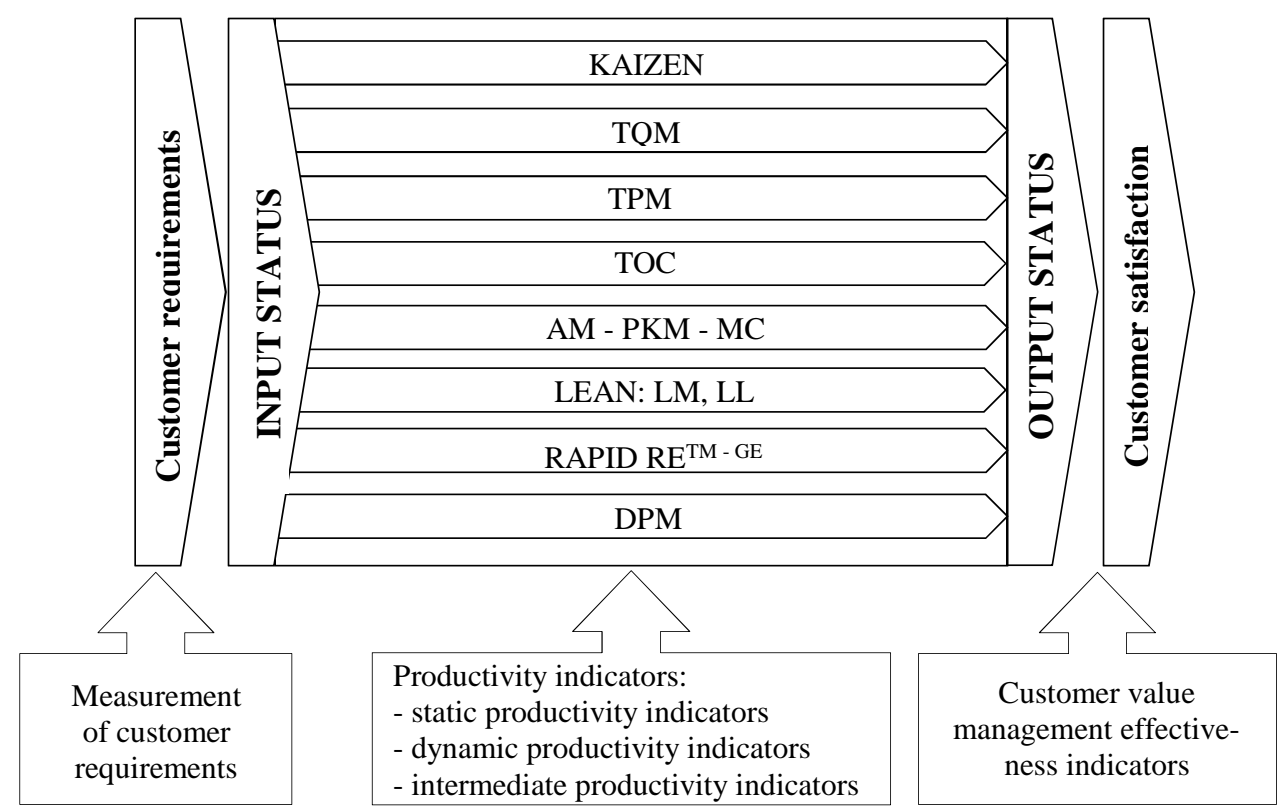

Figure 2. Complex productivity improvement methodology

Source: Author's own study.

The productivity improvement process, as a special type of problem solving activities, should follow the sequence of activities:

1. statement of the objective to be achieved within the organisational entity,

2. diagnosis of the existing state by means of a properly selected measures system, 
3. searching for solutions and choosing the solution to be implemented,

4. planning and implementation of a program of improvements,

5. control of the results obtained.

The productivity improvement concept assumes constant observation, analysis and rationalisation of systems. Such a course of action should be repeated in each organisational unit of the system in relation to each productivity improvement project.

In Fig. 2 a comprehensive productivity improvement methodology has been presented.

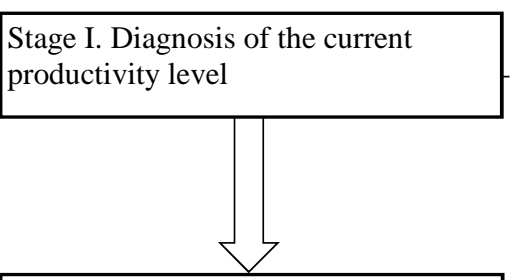

Stage II. Planning and designing a productivity improvement system

Stage III. Implementation of the developed productivity improvement system

Stage IV. Verifying and correcting the functioning of the productivity improvement system to address non-conformities, improve efficiency and effectiveness of its operation

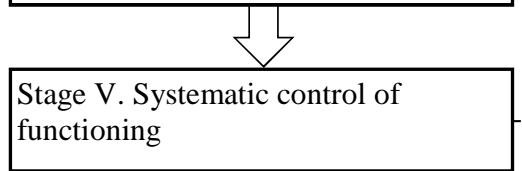

1. Identification of processes affecting productivity.

2. Selection of productivity measures.

3. Primary productivity audit.

4. Summary of the list of needs needed to improve productivity.

1.

1. Developing a productivity improvement strategy.

2. Designing system documentation focused on the implementation of the previously developed strategy.

3. Decomposition of developed plans, projects and schedules into detailed operational documents indicating tasks to be performed by particular organisational units, management or employees in the form of assignments of tasks, duties and powers.

L

1. Training of contractors and system participants.

2. Management decisions introducing the obligation to follow the guidelines contained in the introduced system documents.

3. Adaptation to new solutions.

L_-

1. Monitoring of all system components.

2. Secondary productivity audit.

3. Corrective actions.

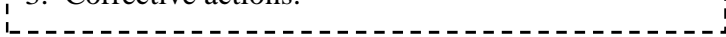

1. Periodic reviews of the overall functioning of the im plemented productivity improvement system.

2. Preventive actions.

Figure 3. Complex productivity improvement methodology implementation stages

Source: Author's own study.

An important issue in the functioning of the productivity improvement process is selection of the management concept (one or more), which will be followed by the desired 
changes. The subject literature indicates that the selection of the methods and their effectiveness depends, to a large extent, on the specific nature of the enterprise. An important role is played by factors such as business orientation and organisational culture, depending on people, their preparation, experience, readiness for change and the ability to solve problems as a team.

In order to analyse and design a productivity improvement methodology in a production company, and to ensure its proper and effective functioning, it is necessary to carry out a number of organisational, technical and social tasks in stages (Fig. 3).

These stages are valid both in the case of changes of local nature, resulting in an improvement in productivity at the level of a manufacturing centre or a group of jobs as well as in those that encompass the entire enterprise. These changes may be a series of minor modifications, but also innovative projects.

\section{CONCLUSION}

Summing up this discussion, it should be stated that there is a wealth of methods and techniques used to improve productivity, especially on a microscale. Some of these methods are universal and can be used in all organisations, while others are dedicated to manufacturing companies.

The developed comprehensive methodology for improving productivity organizes the process of implementing modern concepts, methods and techniques aimed at increasing productivity, taking advantage of their complementary nature and synergy resulting from the use of common detailed tools. This methodology can assist manufacturing companies in programming productivity improvements in the production management area. Its advantage is that it puts emphasis on the balanced and harmonious implementation of modern management concepts.

The advisability of further research and scientific work in the following areas should also be pointed out:

- possible inclusion of new management concepts in the methodology,

- new research to give answers to the question whether the degree of implementation of productivity-oriented concepts, methods and techniques depends on factors such as the size of the enterprise, organisational and legal form and the length of time it has been operating on the market,

- identification of barriers to the implementation of the management concept.

Research on the above problems should contribute to further work on perfecting the productivity improvement methodology, which will allow to control the multitude of new concepts and trends in production management for the benefit of productivity growth in organisations.

\section{REFERENCES}

Danielak, W. (2008). Application of modern management concepts in the SME sector [in:] Weiss, E., Godlewska, M., Bitkowska, A., ed., Nowe trendy $i$ wyzwania $w$ zarzadzaniu. Koncepcje zarzadzania [New trends and challenges in management. Management concepts]. Warsaw: Wyd. VIZJA PRESS \& IT.

Dincută-Tănasea, I., Bordea, C., Câmpeana, E., Pop, D. (2014). Productivity of DMUs: A proposed framework. "Procedia Economics and Finance", No 15. 
Hammer, M., Champy, J. (1996). Reengineering w przedsiębiorstwie. Warszawa: Neumann Management Institute.

Harrington, H.J. (1991). Business Process Improvement - the Breakthrough Strategy for Total Quality, Productivity and Competitiveness. New York: Mc Graw-Hill.

Harris, R., Harris, Ch., Wilson, E. (2005). Doskonalenie przeptywu materiatów [Improving material flow]. Wrocław: Wrocław Technology Transfer Centre.

Imai, M. (2006). Gemba Kaizen. Warsaw: MT Biznes.

Jones, D., Womack, J. (2007). Zobaczyć całość. Mapowanie rozszerzonych strumieni wartości [To see the whole picture. Mapping extended value streams]. Wrocław: Wrocław Technology Transfer Centre.

Kulkarni, P.P., Kshire, S.S., Chandratre, K.V. (2014). Productivity improvement through lean deployment \& work study methods. "International Journal of Research in Engineering and Technology”, Vol. 03, No. 02.

Kosieradzka, A. (2012). Zarzadzanie produktywnościa $w$ przedsiębiorstwie [Productivity management in a company]. Warsaw: Wyd. C.H. Beck.

Kosieradzka, A., Lis, S. (2000). Produktywność. Metody analizy, oceny i tworzenia programów poprawy [Productivity. Methods of analysis, evaluation and design of improvement programs]. Warsaw: Wyd. Politechniki Warszawskiej.

Lareau, W (2009). Filozofia Kaizen w biurze [Kaizen's philosophy in the office]. Gliwice: Helion.

Pacholski, L., Cempel, W., Pawlewski, P. (2009). Reengineering. Reformowanie procesów biznesowych i produkcyjnych $w$ przedsiębiorstwie [Reengineering. Reforming business and production processes in a company]. Poznań: Wyd. Politechniki Poznańskiej.

Piętowska-Laska, R. (2015). Analysis and assessment of productivity of work in a company. 2nd International Multidisciplinary Scientific Conference on Social Sciences and Arts. SGEM 2015, "Economics and Tourism", Conference Proceedings, Book 2, Vol. III, Sofia.

Industrial Statistical Yearbook 2016 (2017). Warsaw: GUS (National Statistical Office Statistics Poland).

Industrial Statistical Yearbook 2017 (2018).Warsaw: GUS (National Statistical Office Statistics Poland).

Rostek, M., Knosala, R. (2014). Badanie produktywności procesów logistycznych w przedsiębiorstwie produkcyjnym [Survey of productivity of logistic processes in a manufacturing company]. „Zarządzanie Przedsiębiorstwem”, No. 1.

Salaam, H.A., How, S.B., Faisae, M.F. (2012). Productivity improvement using industrial engineering tools. "Materials Science and Engineering", Vol. 36, No 1, 012006 [Access: 10.12.2019]. Access on the Internet: http://iopscience.iop.org/1757-899X/36/1/012006.

Sink, D.S. (1985). Productivity management - planning, measurement and evaluation, control and improvement. New York: John Willey \& Sons.

Vijaya Ramnath, B., Vishal Chandrasekhar, A., Elanchezhian, C., Vinoth Selva Bruce, L., Venkataraman, K. (2014). Value stream evaluation and simulation to improve material flow and productivity. "Applied Mechanics and Materials", Vol. 612.

DOI: $10.7862 /$ rz.2019.hss.42

The text was submitted to the editorial office: November 2019.

The text was accepted for publication: December 2019. 
